\title{
Purple Passion Fruit, Passiflora edulis Sims f. edulis, Variability for Photosynthetic and Physiological Adaptation in Contrasting Environments
}

\author{
Nohra C. Rodríguez ${ }^{1}$, Luz M. Melgarejo ${ }^{1, *(D)}$ and Matthew W. Blair ${ }^{2, *}$ \\ 1 Laboratorio de Fisiología y Bioquímica Vegetal, Departamento de Biología, Facultad de Ciencias, \\ Universidad Nacional de Colombia, Bogotá 111321, Colombia; ncrodriguezc@unal.edu.co \\ 2 Department of Agricultural and Environmental Sciences, Tennessee State University, Nashville, \\ TN 37209, USA \\ * Correspondence: lmmelgarejom@unal.edu.co (L.M.M.); mblair@tnstate.edu (M.W.B.); \\ Tel.: +1-615-963-7467 (M.W.B.)
}

Received: 1 April 2019; Accepted: 6 May 2019; Published: 8 May 2019

\begin{abstract}
Purple passion fruit (Passiflora edulis Sims f. edulis) is a tropical juice source. The goal of this project was to evaluate photosynthetic and physiological variability for the crop with the hypotheses that landraces contain the diversity to adapt to higher elevation nontraditional growing environments and this is dependent on specific parameters of ecological adaptation. A total of 50 genotypes of this crop were chosen from divergent sources for evaluations of their eco-physiological responses in two equatorial locations at different altitudes in the Andes Mountains, a center of diversity for the species. The germplasm included 34 landraces, 8 commercial cultivars, and 8 genebank accessions. The two locations were contrasting in climates, representing mid and high elevations in Colombia. Mid-elevation valleys are typical regions of production for passion fruit while high elevation sites are not traditional. The location effects and variables that differentiated genotypes were determined. Results showed statistically significant differences between locations and importance of physiological parameters related to photosynthesis and water use efficiency. Some landraces exhibited better water status and gas exchange than commercial types. Parameters like maximum photosynthesis, points of light saturation and compensation, darkness respiratory rate, and apparent quantum yield varied between genotype groups. The landraces, commercial types, and genebank entries also differed in content of carotenoids and chlorophylls a and b. Meanwhile, photosynthesis measurements showed that altitudinal difference had an effect on genotype-specific plant growth and adaptation. An important conclusion was that landraces contained the diversity to adapt to the new growing environment at higher altitudes.
\end{abstract}

Keywords: gas exchange; chlorophyll fluorescence; water status; purple passion fruit

\section{Introduction}

The purple passion fruit, Passiflora edulis Sims f. edulis, is known as Gulupa in highland areas of Colombia and is closely related to Maracuja (Portuguese), Maracuyá, Parcha (Spanish), or Tumbo (Quechua) in the rest of South America [1]. As a member of the Passifloraceae family, it is noted for its specialized relationships with pollinators [2]. The crop has potential in other tropical and subtropical regions around the world, but the crop is affected by several serious root rot diseases [3] and the physiological requirements and adaptation characteristics of landraces and varieties are poorly studied $[4,5]$. The range of environments and microclimates found in the different elevations in the Andes Mountains of Colombia, Ecuador, and Peru makes the testing of multiple environments in this region of interest for studies of adaptation and physiology in passion fruit. 
Ecological conditions and limitations plus the response to these environmental characteristics is a part of the study of the plant ecophysiology, an important area of crop agronomy. Eco-physiological studies provide information on the thresholds of responses to the environmental contributions of light, water, and nutrients, specific to each environment and for each genotype. Plant responses depend, of course, on the environment, but also on the genotype of the crop, the genetic background of the variety or accession, and the genotype $\times$ environment interaction. The degree of adaptability, furthermore, allows for adaptation to ecological niches and/or plasticity in response to environmental changes [6]. Ecophysiological evaluations include measuring parameters for water status such as leaf water potential $\left(\psi_{\mathrm{f}}\right)$, stomatal conductance $(\mathrm{gs})$, transpiration rate $(\mathrm{E})$, and use efficiency of extrinsic (WUEe) or intrinsic (WUEi) water. Maximum photosynthetic rate (Amax), and net assimilation rate (A) are approximations of photosynthesis; and are complemented by parameters of carbon fixation, light saturation point, light compensation point, and apparent quantum yield $(\varphi)[7,8]$. Pigment content and maximum photochemical efficiency of PSII $\left(\mathrm{F}_{\mathrm{V}} / \mathrm{F}_{\mathrm{M}}\right)$ are also important [9]. Selection based on ecophysiological studies is a new frontier of plant breeding $[4,10,11]$.

Several of the parameters that affect yield in purple passion fruit have been evaluated, but physiological measurements are complicated by the long period of plant establishment and fruit production $[4,12,13]$. Although the purple passion fruit is considered a species of short duration multiplied by seeds; mature plants can live for several years if they do not face significant agronomic or ecological challenges [4,14-17]. One of the objectives of agronomic management of this perennial crop is to cultivate passion fruits over several years for the highest yield possible. However, diseases, intermittent droughts, and nutrient restrictions begin to reduce yields soon after one or two years of continuous fruit production, especially at warmer mid-elevation sites [4,5,17].

This creates pressure for growers to move up the mountains, and to plant passion fruit at higher elevations where fewer diseases and pests occur. New plantings above $2400 \mathrm{~m}$ elevation are expected to increase due to climate change which is causing many crops to migrate to higher areas of cultivation. However, the low radiation and limited photoperiod of the tropical highlands affect photosynthetic parameters $[7,8,18]$. Moreover, given different climate conditions at higher elevation, water use efficiency should be monitored there. As a result, a constant monitoring of fruit yields at different altitudes and under different solar radiation and water conditions is needed. This is especially true in the mountains of Colombia, where cloud cover reduces available light levels [7,8], the thick canopy of passion fruit also limits the penetration of light. In addition, the amounts of rain, mist, fog, and humidity vary according to the ecological niche in which the crop is cultivated.

In summary, purple passion fruit production has been common in mid-altitude valleys with this tradition going back to the late 1700s when botanists Alexander Von Humboldt and Father Mutis were exploring 'New World' plants. Historical reports of plant adaptations by the Colombian geographer and patriot Francisco de Caldas confirmed this to be a widespread practice 200 years ago. Additional field reports for the species up to this century found the range of distribution of the species to be between 1600 and $2200 \mathrm{~m}$ above sea level or $\mathrm{m}$ a.s.l. $[4,5,14,19]$. However, data from our own collections have established that the species distribution reaches up to $2800 \mathrm{~m}$ a.s.l. Taking into account that most cultivar selection to date has been done at warmer and wetter mid-elevation commercial environments but that species has been moving to colder and drier high elevation areas, we hypothesize that some landraces will have good productivity in relation to cultivars.

The goal of our study, therefore, was to evaluate 50 purple passion fruit genotypes at contrasting mid- and high-elevation sites for agroecological parameters of water status, gas exchange and chlorophyll fluorescence among others. The genotypes were of three different origins: commercial varieties, recently collected landraces and genebank accessions from the National Germplasm Bank of Colombia. We discuss the relationship of physiological parameters with adaptation, agronomic potential, and productivity. We found that some landrace accessions have traits for more efficient acclimatization to higher altitude sites where colder and drier conditions are often found, requiring specific adaptation that the commercial varieties or genebank accessions do not have. 


\section{Materials and Methods}

\subsection{Plant Accessions Used in the Study}

A total of 50 accessions or genotypes of "gulupa" type purple passion fruit were evaluated (Supplementary Table S1). Each genotype was given a collection entry number based on the time of collecting by the Plant Physiology laboratory of the department of Biology in the National University of Colombia, known in Spanish as the Departamento de Biología-sede Bogotá, Laboratorio de Fisiología Vegetal (BBFV). These included 8 genebank accessions held by the Colombian national program, 8 commercial cultivars, and 34 landrace genotypes collected from farms in the Colombian departments (equivalent to states) of Antioquia, Boyacá, Cauca, Cundinamarca, Huila, Nariño, Putumayo, Quindío, Risaralda, Santander, Santander del Norte, and Tolima. The Colombian genebank for passion fruit is located in the "La Selva" Experiment station of AGROSAVIA (before known as Corpoica) in the municipality of Rionegro department of Antioquia, where plants are maintained in situ on trellises with a backup of seed from the original collections.

\subsection{Study Locations and Their Characteristics}

Two experimental locations were established during the 2016 growing season for this study, both being on-farm, however each one representing contrasting elevation and microclimate agro-ecologies within the Boyacá-Cundinamarca highlands, a highly productive region of Colombia where many agricultural products, including purple passion fruit, find a ready market in the capital city of Bogotá. The first location was near the town of Pasca, on the farm 'Finca Carolina' located at the latitude/longitude coordinates of $4^{\circ} 18.671^{\prime} \mathrm{N} ; 74^{\circ} 20.116^{\prime} \mathrm{W}$ at an elevation of 1800 meters $(\mathrm{m})$ above sea level (m a.s.1.) and located on the Fusagasugá-Pasca-Cundinamarca highway. The second site was near the town of and in the municipality of Susacón, on the farm "Finca Cartago" located at coordinates $6^{\circ} 143.2^{\prime} \mathrm{N} ; 72^{\circ} 41.5^{\prime} \mathrm{W}$, at an elevation of $2500 \mathrm{~m}$ a.s.l. on the Susacón-Soatá highway. Rainfall and exact average $24 \mathrm{~h}$ period temperatures were measured at the on-farm locations with weather stations (COLTEIN Ltd.a. Bogotá, Colombia) with data loggers and HOBO U12-006 (Onset Computer Corporation, Bourne, MA, USA) that monitored the relative humidity (\%) and temperature. The photosynthetically active radiation (PAR) was measured with LI 190 B sensors on a LI-COR6400 (LI-COR Inc. Lincoln, NE, USA) every 15 min.

\subsection{Experimental Plot Design and Establishment}

All the accessions in each site were planted at a density of 2000 plants/ha. Plant method and distances were based on accepted agronomic practices for the crop. Distances of $2.5 \mathrm{~m}$ between plants and $2 \mathrm{~m}$ between rows were used. Plants were held up in a vertical espalier by a double wire trellis system. A completely randomized block design with six repetitions per accession was used at each location or agroecology. Prior to planting, soil analyses for N, P, and K as well as micronutrients were conducted at each location by collecting a random set of subsamples of soils from across the planting location and mixing them before taking two technical replications for mineral analysis. An HI 83,225 (C225) photometer (HANNA Instruments, Woonsocket, RI, USA) was used for nutrient analysis and $\mathrm{pH}$ measurements.

\subsection{Ecophysiological Parameters}

\subsubsection{Water Status}

Leaf water potential $\left(\Psi_{\mathrm{f}}\right)$ was measured for plants during fruiting stage with a Schöllander pump (Model 1000, from PMS Instruments Co, Albany, OR, USA) at two times in the same day, once prior to dawn (at 4:00 a.m., $\Psi_{4}$ ) and once at mid-day (12:00 p.m., $\Psi_{12}$ ), selected based on results of a previous study [7]. Soil water potential ( $\Psi$ s) was measured with a vacuum gauge tensiometer Model ISR (de 0 a 100 cbar) used at the base of a randomly selected passion fruit plants in each plot. 
The atmospheric water potential $\left(\Psi_{\mathrm{a}}\right)$ was measured according to [20] at the same time as the day as the readings of leaf water potential (4:00 a.m. and 12:00 p.m.). The vapor pressure deficit (VPD) was calculated according to [21]. Transpiration rate (E), photosynthetic rate (A), stomatal conductance (gs) were measured with an IRGA gas analyzer (ADC LCPro+, Bioscientific Ltd., Hoddesdon, UK) during daylight hours between 8:00 a.m. to 5:00 p.m., with a temperature of $25^{\circ} \mathrm{C}$, a $\mathrm{CO}_{2}$ concentration of $380 \mathrm{ppm}$, a relative humidity of $60 \%$, and light at saturation point. These parameters were evaluated in healthy, mature leaves fully exposed to light and in the middle third of the plants.

Extrinsic water use efficiency (WUEe) was calculated from the same data gathering described above using the relationship between photosynthesis and transpiration rates with the formula: WUEe $=\mathrm{A} / \mathrm{E}$. This value allowed us to calculate the balance between water loss versus $\mathrm{CO}_{2}$ fixation and showed whether the purple passion fruit accessions were implementing physiological water conservation mechanisms or not. Intrinsic water use efficiency (WUEi) was calculated with the formula: WUEi $=\mathrm{A} / \mathrm{gs}$, a value which shows the relationship between photosynthesis and stomatal conductance, as dependent on atmospheric water vapor conditions [22,23].

\subsubsection{Gas Exchange}

Photosynthesis light response curves were taken between 8:00 a.m. and 1:00 p.m., assuming a $\mathrm{CO}_{2}$ concentration of $380 \mathrm{ppm}$, a relative humidity of $60 \%$ and PAR of 1200, 1000, 800, 600, 400, 200, 100, 50, 25 and $0 \mu \mathrm{mol}$ photons $/ \mathrm{m}^{2} \mathrm{~s}$ with Licor 6400 (Licor Corp., Lincoln, NE, USA). The response curves were better fitted with the non-linear regression curve of the hyperbolic model of the Michaelis-Menten photosynthesis equation $[8,24]$ compared to the Mitscherlich model $[8,24,25]$ which did not fit well. Therefore, net photosynthesis was calculated as $\mathrm{A}=\left[\left(\mathrm{A}_{\max } \mathrm{PFD}\right) /(\mathrm{K}+\mathrm{PFD})\right]-\mathrm{Rd}$, where $\mathrm{A}_{\max }$ is the rate of photosynthesis at full light saturation, $\mathrm{K}$ is the constant for light saturation below half of the natural photon flux (PFD) and Rd is the dark respiration rate. The light compensation point (Ic) was calculated with the equation Ic $=(K \times R d) /($ Amax $-R d)$. The apparent quantum yield $(\varphi)$ was based on the slope of the linear regression corresponding to the number of photons absorbed in order to fix 1 mole of $\mathrm{CO}_{2}$. The source of the values for the parameters are shown for a typical photosynthesis light response curve (Figure 1) adapted from [20].

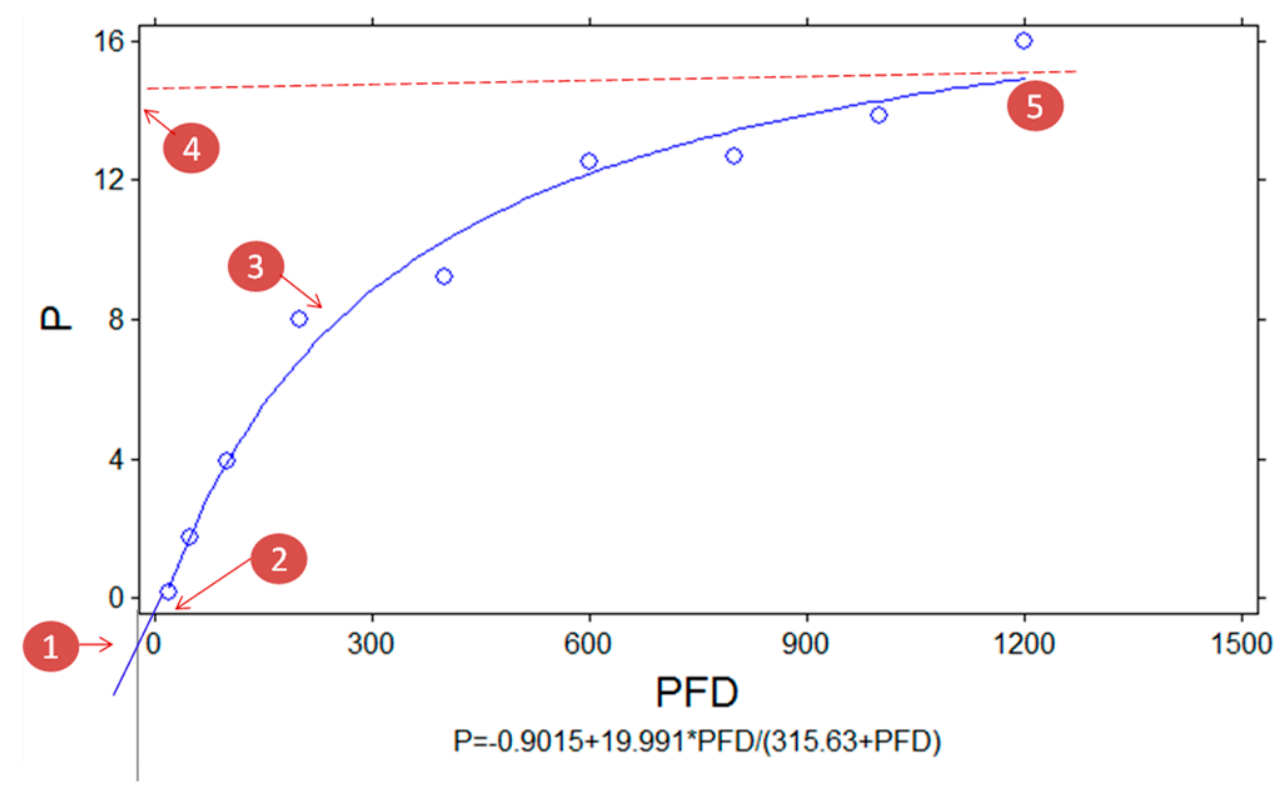

Figure 1. Photosynthesis light response curves is non-linear and regression fitted. Red numbers: 1. Dark respiration rate (Rd), 2. Light compensation point (Ic), 3. Apparent quantum yield $(\varphi)$, 4. Rate of photosynthesis at light saturation point (Amax), 5. Light saturation point. 


\subsubsection{Carotenoids, Chlorophylls Content, and Chlorophyll Fluorescence}

Leaf discs were taken from the leaves of each purple passion fruit plant to measure the content of chlorophyll and carotenoids. The diameters of the leaf discs were $\theta=1.5 \mathrm{~cm}$ wide and were obtained with a hole puncher. The sampling was done at the stage of fruit production as this is the plant state with the highest nutritional and moisture requirements during the plants' life cycle in addition to being suspected as the critical stage for determining yield potential. Pigment extraction and quantification were according to methods used in previous studies $[20,26]$.

The maximum photochemical efficiency of PSII $\left(\mathrm{F}_{\mathrm{V}} / \mathrm{F}_{\mathrm{M}}\right)$ was calculated in dark-adapted leaf at pre-dawn (4:00 a.m.), with an un-modulated fluorometer. the HANDY PEA (Hansatech, UK), where the variable fluorescence $\left(\mathrm{F}_{\mathrm{V}}\right)$ corresponded to the difference between the minimum fluorescence $\left(\mathrm{F}_{0}\right)$, found in darkness when all the reaction centers of PSII are open after a prolonged period without light, compared to the maximum fluorescence $\left(\mathrm{F}_{\mathrm{M}}\right)$ in a period of light when all the reaction centers are closed $[9,27]$. The measurements were determined with the same leaves as described in Section 2.4.1.

\subsection{Yield per Accession or Genotype}

Plant yields were determined at the end of the first production cycle, as the kilogram $(\mathrm{kg})$ of fresh fruit produced per plant. The end of the first production cycle generally occurred nine months after planting which coincides with a first flush of flowering and fruit production that is followed by more minor harvests. As perennial plants, purple passion fruits continue to produce fruit throughout a several year period but it was impractical to conduct the experiment over more than a single year as we used rented farmer's fields for the plantings.

\subsection{Statistical Data Analysis}

A nested analysis of variance (Nested-ANOVA) was conducted for all the variables based on the locations (Pasca and Susacón) and other sources of variation: (1) between groups of genotypes by origin (landraces $n=34$, commercial cultivars $n=8$, and genebank accessions $n=8$ ), and (2) within genotypes by origin (accessions belonging to each group according to their source). The number of biological replicates was equivalent to the number of plants per accession $(n=6)$. In addition, three technical replicates $(n=3)$ were conducted for IRGA evaluations and pigment measurements. Non-normal data were normalized with parametric tests in Excel v.16.0 (MS Office). Variance inflation analysis (VIF), as a measure of the amount of multi-collinearity in a set of multiple regression variables [28], was used to determine the parameters most affecting variation within location or genotype group. Once the non-structured, independent variables were identified, principal component analyses (PCA) was used to compare the groups of accessions based on their origin or type of genotype, with each of the three categories: cultivars, landraces, and gene bank accessions.

\section{Results}

\subsection{Agroecological Site Characterization}

The meteorological characteristics of the two on-farm locations used in Pasca and Susacón showed differences in their agro-ecology and environmental conditions. Precipitation was higher in Susacón than in Pasca; however, both locations had bimodal rainfall patterns with precipitation that could be divided into the two equatorial rainy seasons peaking in April to May and October to November. The precipitation values for the two rainy season periods were $162-185 \mathrm{~mm}$ and $147-169 \mathrm{~mm}$, respectively, in Susacón; and 119-136 mm and 102-125 mm, respectively, in Pasca. However, rainfall in January, during the height of the dry season, was similar in Susacón and Pasca with 31 and $32 \mathrm{~mm}$, respectively, falling in that month. Pasca had a range in average monthly temperatures from 15.8 to $19^{\circ} \mathrm{C}$, but most months were closer to the average for the site of $18^{\circ} \mathrm{C}$. Temperatures were lower in the higher elevation site as was to be expected. Monthly temperatures ranged from 10.4 to $15.2^{\circ} \mathrm{C}$ and averaged $13.1^{\circ} \mathrm{C}$ across the year in Susacón. Relative humidity (RH) fluctuated between 78 and 98\% in Pasca. Meanwhile, 
RH was lower in the colder site of Susacón, fluctuating between 60 and $87 \%$. Daily photoperiod was close to $12 \mathrm{~h}$ as the sites were within $500 \mathrm{Km}$ of equator. However, photosynthetically active radiation (PAR) values ranged rather narrowly from 300 to $400 \mu$ moles of photons $/ \mathrm{m}^{2} \mathrm{~s}$ in Pasca. The range showed more variability, from 192 to $480 \mu$ moles of photons $/ \mathrm{m}^{2} \mathrm{~s}$, in Susacón. PAR values were higher between 9:00 a.m. and 12:00 p.m. for both locations. The peak PAR value, around noon, reached $850 \mu$ moles of photons $/ \mathrm{m}^{2} \mathrm{~s}$ in Susacón and $910 \mu$ moles of photons $/ \mathrm{m}^{2} \mathrm{~s}$ in Pasca.

The differences in temperature, humidity, and PAR reflected differing elevation and contrasting overall climates with more cloudiness in Pasca than in Susacón, based on the effect of mist formation and slope gradient and orientation along the mountain ranges in the first of these sites, as well as the open plateau nature of highland production in the second of these sites. Soil difference might also have been important. The main differences between Pasca and Susacón soils were in $\mathrm{pH}$ (5.2 and 7.4, respectively); interchangeable acidity ( 0.91 and $0.63 \mathrm{meq} / 100 \mathrm{~g})$ and bulk density $\left(1.42\right.$ and $\left.1.28 \mathrm{~g} / \mathrm{cm}^{3}\right)$. The soils were categorized as sandy loam and loamy, respectively, for the two farms.

Environmental conditions at the two locations were also different in terms of the soil $\left(\Psi_{\mathrm{S}}\right)$ and atmospheric $\left(\Psi_{a}\right)$ water potentials available to affecting the water potential of the plants. It was noteworthy that there were differences in water potential between locations, with $0.27 \mathrm{kPa}$ in Susacón and $0.12 \mathrm{kPa}$ in Pasca; and that water availability to the plants were most different for the two locations at mid-day (Table 1).

Table 1. Atmospheric $\left(\psi_{\mathrm{a}}\right)$ and soil $\left(\psi_{\mathrm{s}}\right)$ water potential \pm standard deviation measured (in MPa) at pre-dawn (4:00 a.m., $\left.\psi_{4}\right)$ and mid-day (12:00 p.m., $\left.\psi_{12}\right)$ for the two on-farm locations of the study. Values in parentheses indicated the corresponding temperature in degrees Kelvin followed by the relative humidity.

\begin{tabular}{ccccc}
\hline & \multicolumn{2}{c}{ Pasca $1800 \mathrm{~m}$ a.s.l. } & \multicolumn{2}{c}{ Susacón $2500 \mathrm{~m}$ a.s.l. } \\
\cline { 2 - 5 } & $\psi_{\mathbf{1 2}}$ & $\boldsymbol{\psi}_{\mathbf{4}}$ & $\boldsymbol{\psi}_{\mathbf{1 2}}$ & $\boldsymbol{\psi}_{\mathbf{4}}$ \\
\hline$\psi_{\mathbf{s}}(\mathrm{MPa})$ & $-0.01 \pm 0.003$ & $-0.01 \pm 0.002$ & $-0.02 \pm 0.001$ & $-0.01 \pm 0.002$ \\
\hline$\psi_{\mathbf{a}}(\mathbf{M P a})$ & $-36.9(292 / 76)$ & $-15.5(288 / 89)$ & $-67.8(288 / 60)$ & $-27.5(283 / 81)$ \\
\hline
\end{tabular}

\subsection{Ecophysiological Parameters}

\subsubsection{Water Status for Passion Fruit Genotypes at Mid-Elevation and High-Elevation Locations}

The leaf water potential $(\Psi)$ showed highly significant differences in the nested ANOVA between locations and between genotypes ( $p$-value $<0.005$ ), but not among groups of genotypes ( $p$-value $>0.1$ ) (Figure 2). The water potential in high elevation Susacón was significantly lower ( $p$-value $<0.005)$ than in mid elevation Pasca, indicating that the genotypes were exposed to water deficit at the higher compared to the lower site. The landrace genotypes presented less negative leaf water potential for both locations, with lower $\Psi_{12}$ in Pasca for genotypes BBFV006, 020, and $024\left(\Psi_{12}<-0.45\right)$ and in Susacón for BBFV006, 024, and $016\left(\Psi_{12}<-0.6\right)$. 


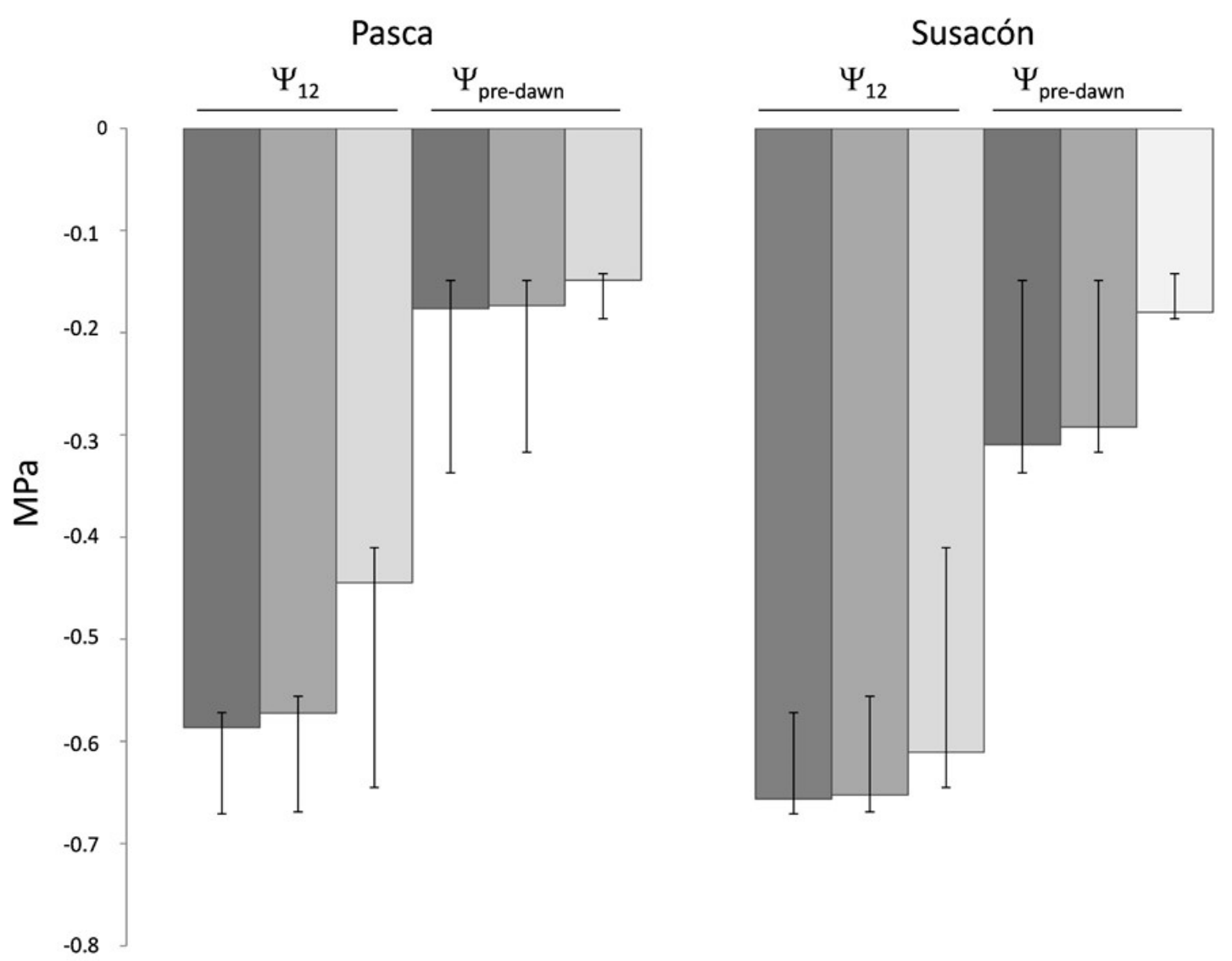

Figure 2. Leaf water potential measured in MPa for groups of purple passion fruit (Passiflora edulis f. edulis) germplasm accessions planted in two locations (Pasca at $1800 \mathrm{~m}$ a.s.l. and Susacón at $2500 \mathrm{~m}$ a.s.l.) separated based on their origin as cultivar accessions (dark bars), genebank accessions (medium gray bars) or landraces (light gray bars). Leaf water potentials were measured at pre-dawn $\left(\psi_{4: 00 \mathrm{~h}}\right)$ and mid-day $\left(\psi_{12: 00 \mathrm{~h}}\right)$. Germplasm collections consisted of 34 landraces, 8 cultivars, and 8 genebank accessions. Nested-ANOVA results at $p<0.005$. The error bars indicate the standard deviation.

\subsubsection{Gas Exchange Variability}

The results of the Nested-ANOVA for locations and genotype groups (commercial cultivars, genebank accesions, landraces) showed significant differences $(p$-value $<0.01)$ for most of the ecophysiological parameters (gas exchange, water status, and content of pigments), but not for yield values. As an example, the landraces were adapted physiologically but also presented good yields above $2.5 \mathrm{~kg} /$ plant, despite not having been part of a selection program. The higher rate of photosynthesis, and greater stomatal conductance observed in the lower elevation site of Pasca compared to the highest elevation site of Susacón was notable. It is important to indicate that many of the commercial cultivars and genbank accessions were from the traditional mid-elevation growing regions while landraces were from all regions of Colombia at mid to high elevations.

\subsubsection{Photosynthesis Rate (A), Transpiration Rate (E) and Stomatal Conductance (gs)}

Photosynthesis rate (A) showed differences between locations, genotypes ( $p$-value $<0.0001$ ) and groups of genotypes ( $p$-value $=0.07$ ) (Figure 3$)$. Landraces presented higher photosynthetic rates than genebank accession or commercial cultivars. Meanwhile, the transpiration (E) and stomatal conductance (gs) variables showed smaller differences between locations or groups of genotypes ( $p$-value $>0.07)$, than among genotypes ( $p$-value $<0.0001)$. Gas exchange, as measured by $\mathrm{E}$, was lower in landraces than in the other two groups. Stomatal conductance, gs, was lower for landraces in the same comparison, but only in Susacón not in Pasca. 

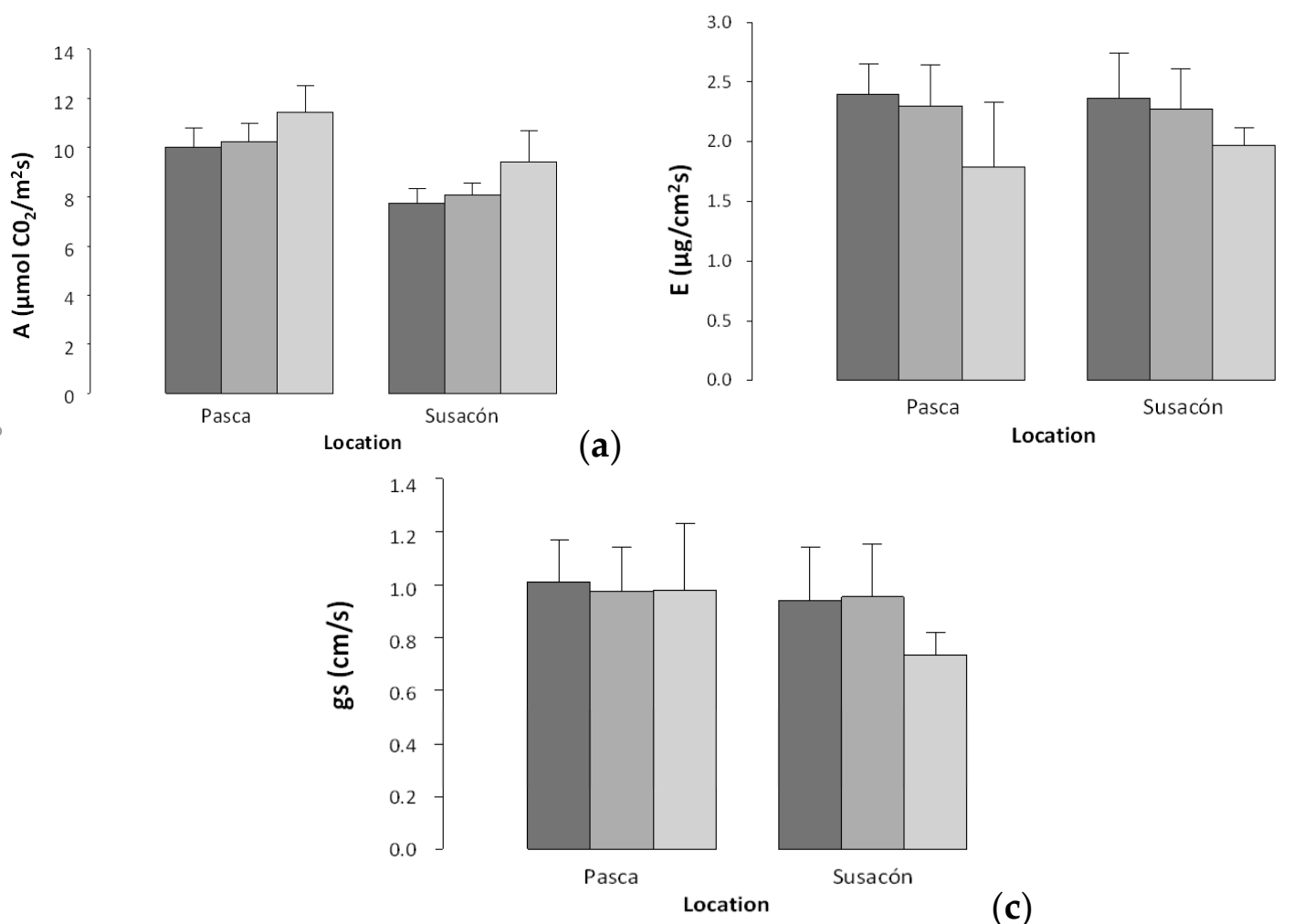

(b)

Figure 3. Average photosynthesis rate (A) (a), transpiration rate (E) (b) and stomatal conductance (gs) (c) for three groups of passion fruit (P. edulis $\mathrm{f}$ edulis) genotypes evaluated in this study: cultivars (dark gray bar), genebank accessions (medium gray bar), and landraces (light gray bar) grown across two environments, Pasca at $1800 \mathrm{~m}$ a.s.l. and Susacón at $2500 \mathrm{~m}$ a.s.l. Nested-ANOVA results at $p<0.005$.

The error bars indicate the standard deviation.

\subsubsection{Water Use Efficiency (WUE)}

Significant differences were observed between locations for WUEe and WUEi (Figure 4) as well as between and within groups of genotypes ( $p$-value $<0.001)$. Landraces had the highest average values for both parameters of water use efficiency and were contrasting to commercial cultivar and genebank accessions. Better WUE was observed in the landraces genotypes BBFV 006, 016, 020, and 024. Among all genotypes, the ones with the best gas exchange values for photosynthesis (more than $10 \mu \mathrm{mol}$ $\mathrm{CO}_{2} / \mathrm{m}^{2} \mathrm{~s}$ in Pasca and $8 \mu \mathrm{mol} \mathrm{CO} / 2 \mathrm{~m}^{2} \mathrm{~s}$ in Susacón) and transpiration (less than $10 \mu \mathrm{g} / \mathrm{cm}^{2} \mathrm{~s}$ in both locations) across both locations were the landraces genotypes BBFV 006, 009, 024, 046, and 047.

However, differential responses between genotypes were seen. For example, BBFV 001, 010, 011, 037, 038, and 046 were best in Pasca. Meanwhile, measurements for the best nine accessions showed BBFV 006, 009, 010, 011, 013, 022, 023, 026, 046, and 047 as best in Susacón (Supplementary Table S2). Commercial cultivars were intermediate between the genebank accessions and the best landraces, but differences were not significant ( $p$-value $>0.07$ ) except for WUEi in Pasca ( $p$-value $<0.05)$. 

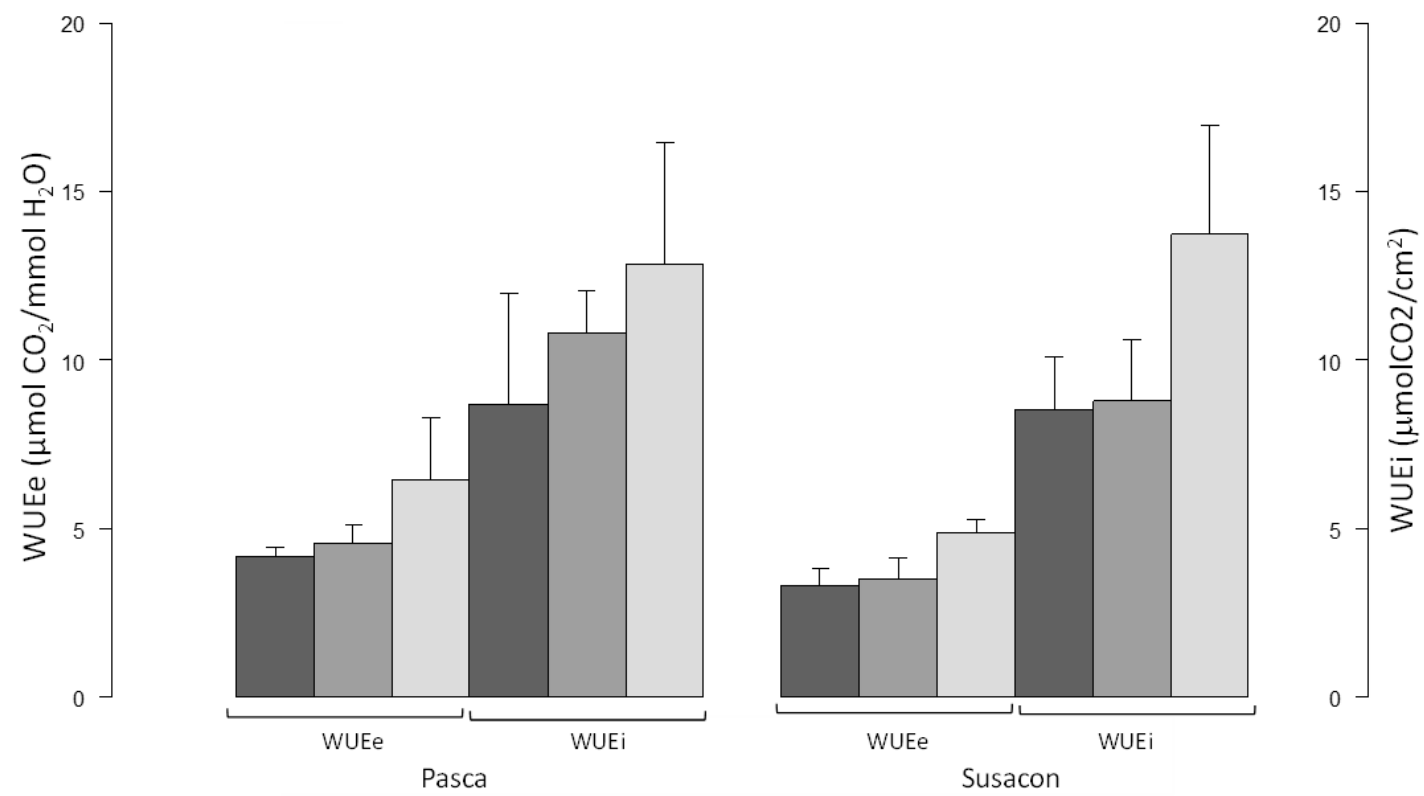

Figure 4. Average extrinsic and intrinsic water use efficiency for three groups of purple passion fruit, $P$. edulis $\mathrm{f}$ edulis, accessions based on their origin: commercial cultivars (dark gray bar), genebank accession (medium gray bar) and landraces (light gray bar) grown across two environments, Pasca at $1800 \mathrm{~m}$ a.s.l. and Susacón at $2500 \mathrm{~m}$ a.s.l. Nested-ANOVA results at $p<0.001$. Error bars indicate the standard deviation.

\subsubsection{Photosynthesis Light Response Curves}

The purple passion fruit genotypes showed highly significant differences in photosynthetic capacity between the two locations, especially in the point of light compensation (Ic) ( $p$-value $<0.0001)$. Among all genotypes, the average Ic value was 30.5 in Pasca and ranged from a minimum of 12.3 to a maximum of $43.2 \mu \mathrm{mol} / \mathrm{m}^{-2} \mathrm{~s}$ as shown for the ten best accessions (Supplementary Table S3). The range in values was lower in Susacón with a mean of $15.1 \mu \mathrm{mol} / \mathrm{m}^{2} \mathrm{~s}$ from a minimum of 9.1 to a maximum of $35.1 \mu \mathrm{mol} / \mathrm{m}^{2} \mathrm{~s}$. Significant differences ( $p$-value $<0.001$ ) in Ic values were also seen between groups of genotypes, but not within groups of genotypes ( $p$-value $>0.05$ ).

In the case of another photosynthetic trait, $A_{\max }$, there were differences among genotypes ( $p$-value $<0.001$ ) but not between locations or groups of genotypes ( $p$-value $>0.05)$. Averages were $18.6 \mu \mathrm{mol} \mathrm{CO} 2 / \mathrm{m}^{2} \mathrm{~s}$ in Pasca and $17.04 \mu \mathrm{mol} \mathrm{CO} 2 / \mathrm{m}^{2} \mathrm{~s}$ in Susacón. The range in genotype value for this parameter, however, were higher in Pasca (11.7 to $26.2 \mu \mathrm{mol} \mathrm{CO} \mathrm{CO}_{2} / \mathrm{m}^{2} \mathrm{~s}$ ) compared to Susacón (10.8 to $21.9 \mu \mathrm{molCO} / \mathrm{m}^{2} \mathrm{~s}$ ). In both locations, the landraces presented higher $\mathrm{A}_{\max }$ values than commercial cultivars or genebank accessions, which were similar to each other. In contrast, PAR $_{\text {sat }}$ showed significant differences among genotypes $(p$-value $<0.0001)$ and locations ( $p$-value $=0.002)$ but not between groups of genotypes ( $p$-value $>0.05$ ). Purple passion fruit plants in Pasca had a PAR sat $_{\text {at }}$ average of $450.3 \mu \mathrm{mol}$ photons $/ \mathrm{m}^{2} \mathrm{~s}$, ranging from 336.1 to 610.2; while in Susacón the average was 588.5 with a range of 510.3 to $716.9 \mu \mathrm{mol}$ photons $/ \mathrm{m}^{2} \mathrm{~s}$. Values were higher for landraces than for other groups in Susacón, but not in Pasca, where cultivar and genebank accessions had higher averages.

The apparent quantum yield $(\varphi)$, also showed significant differences between locations ( $p$-value $<0.001)$, also between and within groups of genotypes ( $p$-value $<0.005)$. Values were higher in Susacón compared to Pasca with averages of 0.043 and $0.035 \mu \mathrm{molCO}_{2} / \mu \mathrm{mol}$ photons, respectively. Minimum and maximum values were 0.023 to 0.067 and 0.021 to $0.058 \mu \mathrm{molCO} / / \mu \mathrm{mol}$ photons, respectively. Overall, the photosynthesis response parameters to light levels were similar in commercial cultivars and genebank accessions but different in landraces across both locations. On the other hand, the rate of respiration, or $\mathrm{Rd}$, presented significant differences between and within accessions ( $p$-value $<0.001$ ), but not between locations ( $p$-value $=0.11$ ), where average values for Pasca and Susacón were 
1.38 and $1.63 \mu \mathrm{mol} \mathrm{CO} 2 / \mathrm{m}^{2} \mathrm{~s}$, respectively. Highest values were 3.21 and $3.5 \mu \mathrm{molCO} / \mathrm{m}^{2} \mathrm{~s}$ respectively for the two locations; while lowest values were 0.12 and $0.11 \mu \mathrm{molCO} / 2 \mathrm{~m}^{2} \mathrm{~s}$. The comparison of genotype groups showed landraces with higher respiration than cultivars and genebank accessions in Pasca, but not in Susacón, where the opposite was true.

The maximum photochemical efficiency of Photosystem II ( $\left.\mathrm{Fv} / \mathrm{F}_{\mathrm{M}}\right)$ was not significantly different between locations and between or within genotypes ( $p$-value $>0.1)$. Among the individual landraces, BBFV007 had an $\mathrm{Fv} / \mathrm{F}_{\mathrm{M}}$ value of 0.71 in Susacón while the rest of the genotypes were around 0.83 .

\subsubsection{Carotenoids, Chlorophylls Content, and Chlorophyll Fluorescence}

Carotenoids, chlorophyll a and total chlorophyll contents showed significant differences among genotypes and locations ( $p$-value $<0.001$ ), but not between groups of genotypes ( $p$-value $>0.05$ ). Chlorophyll $b$, on the other hand only showed differences between groups of genotypes but these were highly significant $(p$-value $=0.006)$. Chlorophyll a content was higher in Pasca, ranging from 1.22 to $1.64 \mathrm{mg} / \mathrm{g}$ fresh weight, compared to Susacón with a range from 1.28 to $1.44 \mathrm{mg} / \mathrm{g}$ (Figure 5). More accessions in Pasca reached the high chlorophyll a content of $1.6 \mathrm{mg} / \mathrm{g}$ including BBFV 006, 009, 021, 023, 024, 039, and C3873; while in Susacón only BBFV 003, 021, 024, 027, 028, and 039 reached the lower threshold of $1.42 \mathrm{mg} / \mathrm{g}$.
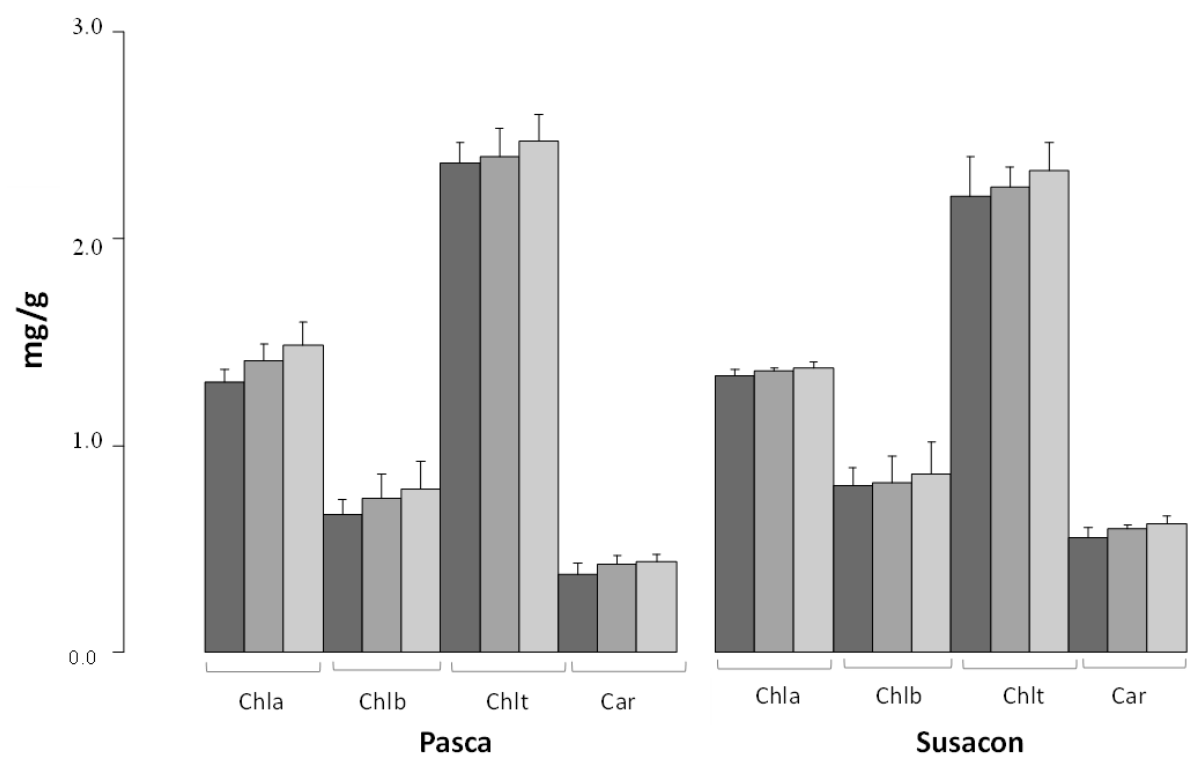

Figure 5. Chlorophyll content for chlorophyll a, chlorophyll b, total chlorophyll and carotenoids in 50 purple passion fruit genotypes grown across two environments, Pasca at $1800 \mathrm{~m}$ a.s.l. and Susacón at $2500 \mathrm{~m}$ a.s.l. The genotypes were grouped according to their origins as: commercial cultivars $(n=8$, dark gray bar), genebank accession ( $n=8$, medium gray bar), and landraces $(n=34$, light gray bar). Error bars indicate the standard deviation.

The genotypes with the highest chlorophyll b content were BBFV 040 in Pasca and BBFV 009 and 024 in Susacón. Carotenoid content was higher in the higher elevation site of Susacón $(0.60 \mathrm{mg} / \mathrm{g}$ fresh weight) than in Pasca $(0.42 \mathrm{mg} / \mathrm{g})$ the lower elevation site. High carotenoid content genotypes were BBFV, 026, 032, 035, 046, and C3869 in the former location and BBFV 035 and 046 in the latter location. As opposed to carotenoid content, the total chlorophyll content was higher in the lower elevation site, Pasca $(2.44 \mathrm{mg} / \mathrm{g})$ than in Susacón $(2.3 \mathrm{mg} / \mathrm{g})$, the higher elevation site. The genotypes with the highest values were BBFV 010, 038, and 041 in Pasca and BBFV 028 in Susacón. In all cases, the landraces were more variable than either the genebank accessions or commercial cultivars, the latter being more homogeneous in their responses. This was perhaps due to the wide-ranging origins of the landraces compared to the other genotype groups. 


\subsection{Integrated Analysis of Ecophysiological Parameters}

Of the 17 ecophysiological parameters evaluated, 10 of them explained most of the variability between genotypes, as determined by analyzing correlations between the traits and eliminating 7 variables with co-linearity above 4 according the method of [29]. The most important parameters were $\psi_{12}$, E and WUEe for either location; Amax, $\varphi, \mathrm{Fv} / \mathrm{F}_{\mathrm{M}}$ and chlorophyll $\mathrm{b}$ in Pasca alone; and PAR, carotenoids and VPD in Susacón alone. Yield was not considered due to its lower heritability than for the ecophysiological parameters. In the PCA conducted with the datasets (Figure 6), the first and second dimensions explained a cumulative $77 \%$ and $86 \%$ of the variability between genotypes in the two locations of Pasca y Susacón, respectively.

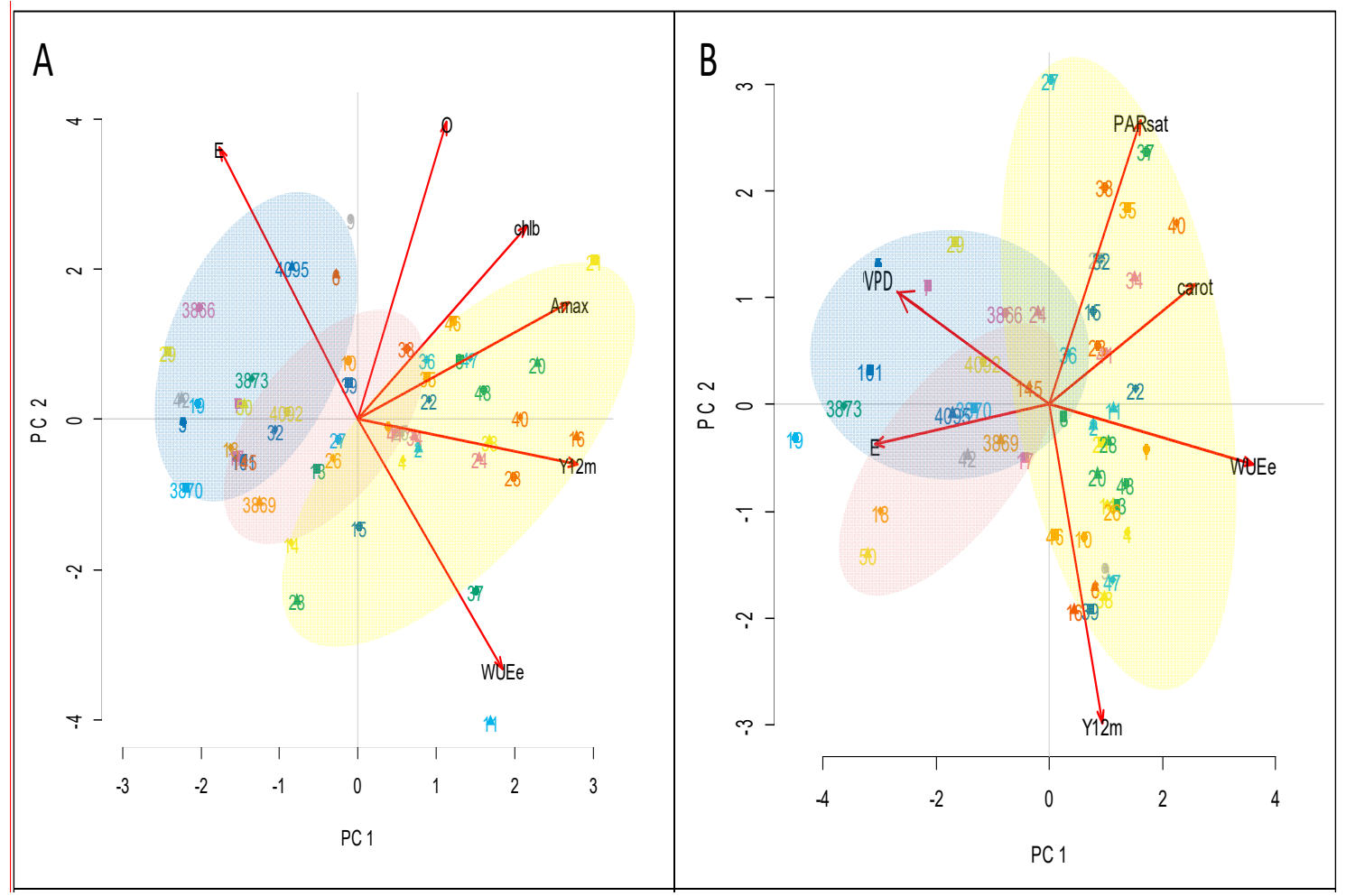

Figure 6. Principal component analysis showing cumulative variance explained (in parenthesis) for the 50 purple passion fruit genotypes in A. Pasca (1800 m.a.s.l); with first and second components PC1 $(45 \%)$ and PC2(32\%). B. Susacón (2500 m.a.s.l) with first and second components PC1 (53\%) and PC2 $(33 \%)$. The blue shaded circle defines genebank accessions; the red circle defines commercial cultivars; and the yellow circle defines landraces. Abbreviations for vector lines are: $E=$ Transpiration rate, $\mathrm{A}_{\max }=$ Maximum photosynthesis, $\mathrm{PAR}_{\text {sat }}=$ photosynthetically active radiation, Carot $=$ carotenoids, $\mathrm{WUE}_{\mathrm{e}}=$ extrinsic water use efficiency, VPD = vapor pressure deficit, $\psi_{12}=$ day leaf water potential.

The most discriminating variables in both locations were those related to water use (such as E, WUEe, VPD, and $\psi_{12}$ ). In Pasca the photosynthetic rate (A) was also discriminating. The accessions show variations in their ecophysiological behavior depending on the location, it is evidenced in the distribution of them in the PCA of both locations. The commercial cultivars and gene bank accessions were close to each other evidencing a similar physiological behavior, while landrace genotypes show a physiological behavior discriminated by variables associated with WUE, photosynthesis, and pigments. Purple passion fruit plants respond to moisture levels and light by modifying the traits that underlie the potential of photosynthesis, such as chlorophyll, other pigments, and the exchange of gases by stomata, resulting in differential rates of fixation of $\mathrm{CO}_{2}$ between genotypes and locations, but not within genotypes, except within the landraces genotypes, that would be expected to be more heterogeneous in eco-physiological adaptation than the other genotypes, given the large range of 
environments from which they were collected many from different environments than the commercial cultivars or the few genebank accessions used. This wide range of responses from the landraces might favor their acclimatization and adaptation to biotic or abiotic stresses across those source environments.

\subsection{Yield of the Genotypes in the Two Locations}

Yields were similar across sites ( $p$-value $>0.05)$. However, we observed highly significant differences ( $p$-value $<0.001$ ) between and within the groups of genotypes (Figure 7). The commercial cultivars and genebank accessions had better average yields in comparison to the landraces. However, we observed that there were genotypes within the latter group that exhibited much better yields than genotypes of the other two groups.
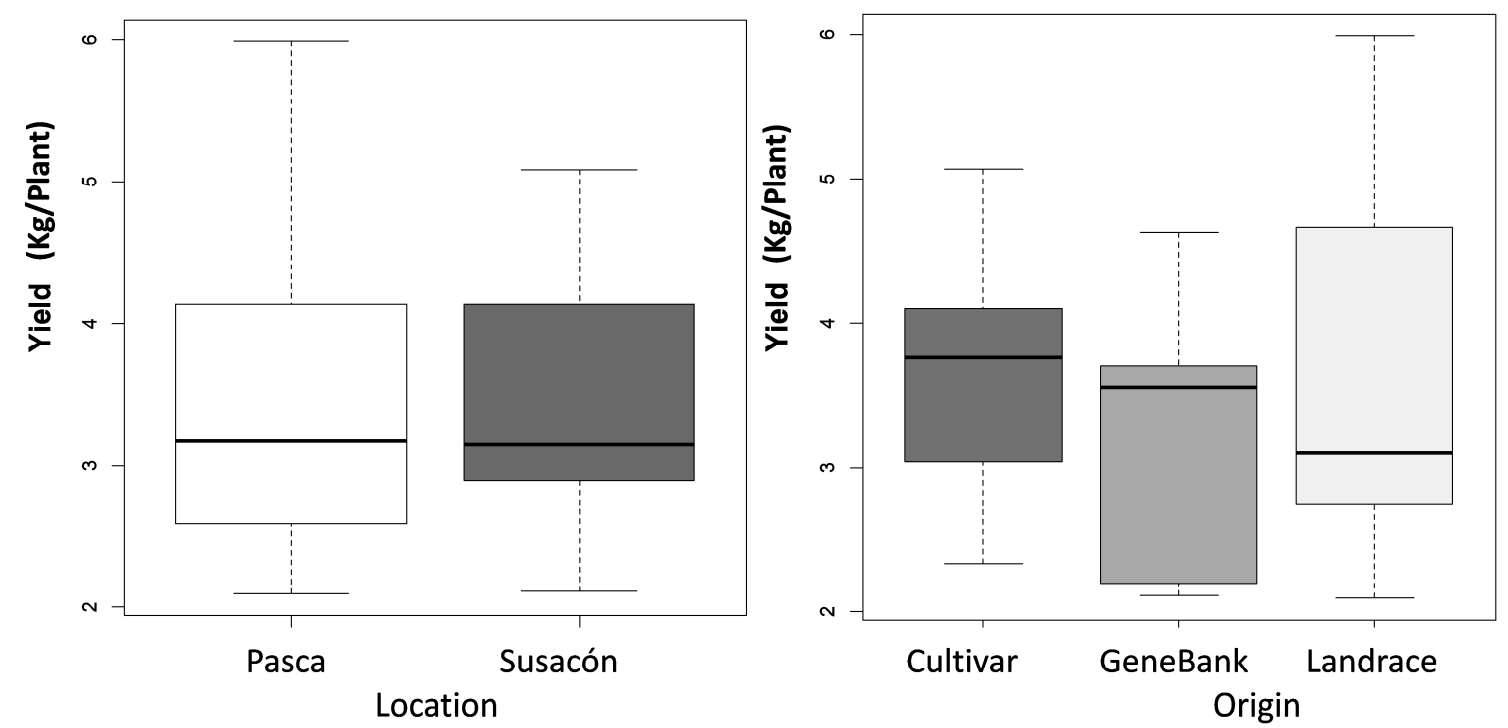

Figure 7. Boxplot of the yield values for purple passion fruit, Passiflora edulis Sims edulis, genotypes in kilograms of fresh fruit per plant produced in the two locations studied and among the groups of genotypes according to their source type.

\section{Discussion}

It was evident that purple passion fruits varied and adapted to the two locations used which represent different ecological niches and climate conditions of mid and high elevation sites found in Colombia and the Andes Mountains. Water use efficiency and photosynthetic efficiency seemed to be needed in combination for the genotypes to adapt to the drier and colder highland site versus the more humid and warmer mid-elevation site. An explanation for this could be greater stomatal conductance in the cooler environment, with greater transpiration and increased gas exchange, especially for $\mathrm{CO}_{2}$, which is the main ingredient for photosynthesis [30,31]. Stomata that remain open for a longer period have the potential to increase carbon fixation, but also water loss [31], and this was evident in the differences in the photosynthetic rates of the purple passion fruit genotypes in the two sites at distinct elevations. However, some landraces showed lower stomatal conductance and transpiration but still had higher photosynthesis rates, making them valuable for increased productivity.

According to $[6,22,23,30,31]$ the maintenance of open stomata depends on leaf hydration levels. The water potential threshold at which stomata close varies between species of plants, but also between the genotypes of the same species [22,31]. This was confirmed for stomatal conductance of purple passion fruits in our study and in the work of $[30,32,33]$ in Brazil. Transpiration rates also vary among purple passion fruits [7,8] and yellow passion fruit [34]. Differences in adaptation to water stress in many crops are most often found in landraces, wild or weedy types, which are often adapted to rain-fed conditions, compared to commercial types, which are often irrigated. Indeed, in both locations and for both measurements at pre-dawn and mid-day, the landraces of passion fruit we studied were 
better adapted than cultivars perhaps due their greater genetic diversity [35]. Overall, landraces could provide high water use efficiency, favorable gas exchange, and photosynthesis traits to use as new selected varieties or breeding material.

The controlled closure or opening of the stomata is a strategy of plants to regulate the flow of water and $\mathrm{O}_{2} / \mathrm{CO}_{2}$ into and out of the leaf $[22,23,36]$; so that if the stomata remain closed, the leaf will lose less water, but will also absorb less $\mathrm{CO}_{2}$, which will reduce the rate of photosynthesis $[8,18,37]$. The opening of stomata during the appropriate periods of vapor pressure is a mechanism that genotypes use to avoid water loss due to a gradient between air in the stomata versus atmosphere thus regulating photosynthesis. Specifically, when stomata are open, they must allow the entry of $\mathrm{CO}_{2}$ without a large loss of water [37,38], a mechanism that improves WUE while allowing carbon fixation [22,23]. The stomata of many species close in response to a difference in vapor pressure between the air and the leaf, the magnitude of this response is genotype-dependent $[23,31,37,39]$, and here we verify that within the species of $P$. edulis we also find variation. Furthermore, in this study, we found that among the genotypes, some landraces showed an efficient use of water without effecting the net photosynthesis rate even while gas exchange was similar between sites. Many genotypes were adapted to the higher, drier environment which makes them promising for production during drought periods or in areas with water deficits.

As additional components of eco-physiological analysis, intrinsic and extrinsic WUE, and leaf water potential, were important for distinguishing growth of the purple passion fruit accessions in the two environments. The plants in Pasca showed better regulation of water use than plants in Susacón. Both WUEe and WUEi were correlated with the rate of transpiration, which is dependent on stomatal opening [22,23], the process through which water loss occurs. Among the genotype groups, WUE was significantly higher for landraces than for other genotypes based on the combination of transpiration and stomatal conductance. On the other hand, the leaf water potential in pre-dawn conditions, compared to mid-day, showed that any water stress was much lower at night when the passion fruit plants recovered their turgidity and hydration, especially in Pasca, the more humid environment. Susacón did have more negative pre-dawn water potential like the corresponding values at mid-day. However, due to lower day temperatures at this higher elevation site, transpiration was not significantly higher there than in the lower elevation site.

Daytime closing of stomata is a mechanism of conserving water by purple passion fruit plants; but conductance measures showed this was not occurring frequently at the higher elevation site despite the low humidity levels. Nighttime adaptation may have been an important factor with overnight recovery of plant water potential aided by lower temperatures and reduced transpiration compared to the day [40]. However, the landrace accessions in comparison with the cultivars and genebank accessions proved to be very efficient in the use of water, especially in drier site of Susacón.

As for the ecophysiological parameters derived from light curves, we found that plants in Susacón responded efficiently to higher saturating solar radiation, which would explain the higher apparent quantum yield for this higher elevation location. The maximum photochemical efficiency of PSII are found when $\mathrm{Fv} / \mathrm{F}_{\mathrm{M}}$ values are around 0.83 [9]. These are the values found in healthy plants, without any stress [27]. Average values for $\mathrm{Fv} / \mathrm{F}_{\mathrm{M}}$ were quite similar for the two locations of Pasca and Susacón.

As a result, we can conclude that photosystem II activities of the purple passion fruit plants were not affected by stress in either environment; nor were there significant differences between locations, between genotype groups or within genotypes. Likewise, differences in the concentration of pigments according to the location were observed, while the photosystems of the purple passion fruit plants were effective. The concentration of leaf Chlorophyll $b$ showed that at high elevations in the Andes Mountains the plants needed protection from excess solar radiation [18]. Plants like P. edulis are known to use a strategy to release excess energy from the photosystem in the form of heat, a process in which pigments such as carotenoids are involved. This would explain why all genotypes of purple passion fruit studied had significantly higher carotenoid content at the higher altitude site of Susacón, where photosynthetically active radiation was higher. Lower concentrations were observed in the 
corresponding plants grown at the lower elevation site of Pasca. Carotenoids in plants growing at high elevation locations also have a protective role for the photosystem of photosynthetically active leaf cell chloroplasts. In contrast, the content of chlorophyll a was lower in all the purple passion fruit genotypes grown in Susacón compared to the corresponding plants grown in Pasca. We can infer that the different solar radiation found in the two locations influenced the adaptive response of purple passion fruit genotypes in the concentration of the chlorophylls.

In summary, the differences between and within groups of genotypes grown in the two different altitudes responded to the climatic variations and sunlight conditions. It is worth noting that microclimates can vary based on interaction with the complex topography of Andean mountains and valleys. For example, the Pasca site was near the high, wet "Paramos" of Sumapaz, which provided a constant source of cloud cover, stream water and humidity throughout the year. This reduces the frequency of low water vapor pressure or stress in the atmosphere there. Susacón, had lower water availability and was in a drier overall environment. Climate change with increases in temperature, rainfall in some areas and atmospheric carbon dioxide concentration generally plus changes in microclimatic patterns are generating new areas for the production of passion fruit [14]. Production is likely to continue to climb up the mountain slopes with farmers moving the crop to higher altitudes in search of adequate temperature regimes.

\section{Conclusions}

This study has implications for the production of purple passion fruit in Colombia and beyond both now and in the future. The two locations and their microclimates, used here represent the range in altitudes used for growing the crop in the Andes of South America and the Highlands of East Africa. Before our study, purple passion fruit was thought to have a maximum production range up to $2200 \mathrm{~m}$ altitude [4]. However, for this study, we collected landraces at locations up to $2700 \mathrm{~m}$ above sea level and for this reason selected a testing site with a higher altitude in Susacón. Landraces were shown to have a broad ecophysiological potential in comparison with the cultivars and genebank accessions. Therefore, it is urgent that we select landraces that can best respond to the changing ecosystem conditions to increase the altitude at which passion fruit grows.

In this selection process, we can include ecophysiological parameters that have been informative to create selection indices for a crop improvement program in purple passion fruits. The story of highland purple passion fruit production can be considered to be a case study in climate change adaptation. Crop adaptations will be easier if the appropriate genotypes are used. In this respect, the results of our study showed that landraces had a broad adaptive response to environmental variations compared to present commercial cultivars and genebank accessions, making them a source of diversity to start a crop improvement program.

Supplementary Materials: The following are available online at http://www.mdpi.com/2073-4395/9/5/231/s1, Table S1: Purple Passion Fruit, Passiflora edulis Sims f. edulis, genotypes and accessions collected and used for this study and their geographical origin in various Departments of Colombia and group identification by source (Landrace, Commercial Cultivar or Genebank Accession), Table S2: Photosynthetic rate (A), transpiration rate (E), stomatal conductance (gs), extrinsic water use efficiency (WUEe) and intrinsic water use efficiency (WUEi) measured for the best nine purple passion fruit genotypes Passiflora edulis Sims f. edulis, from the Bogotá Universidad Nacional (BBFV) series grown in two production locations: Pasca and Susacón at different elevations in meters above sea level ( $\mathrm{m}$ a.s.l). Total genotypes included 34 landraces, 8 commercial cultivars, and 8 genebank accessions. Asterisks indicated the best genotypes for gas exchange, Table S3: Derived parameters for photosynthetic light response in the best 10 genotypes of purple passion fruit, Passiflora edulis Sims f. edulis, grown in two production locations, Pasca and Susacón at different meters above sea level (m a.s.l). The traits, \pm standard deviation, included $\mathrm{A}_{\max }=$ maximum photosynthesis rate, $\mathrm{PAR}_{\mathrm{sat}}=$ photosynthetically active radiation at saturation of light, $\mathrm{Rd}=$ rate of dark respiration, Ic = point of light compensation, $\varphi=$ apparent quantum yield based on the number of photons absorbed to fix one mole of $\mathrm{CO}_{2}$. Total genotypes included 34 landraces, 8 commercial cultivars, and 8 genebank accessions. Asterisks indicated maximum values obtained for each parameter found in the best 10 genotypes with the averages for each group of genotypes (landraces, commercial cultivars, and genebank accessions).

Author Contributions: Conceptualization, L.M.M., and N.C.R.; Methodology, N.C.R., L.M.M., and M.W.B.; Formal Analysis, N.C.R., L.M.M., and M.W.B.; Investigation, N.C.R.; Writing-Original Draft Preparation, N.C.R., L.M.M., and M.W.B.; Writing-Review \& Editing, L.M.M. and M.W.B.; Funding Acquisition, L.M.M. and M.W.B. 
Funding: Colciencias and Universidad Nacional de Colombia providing funding for the supplies and student scholarship to NRC for the project "Eco-physiology, mineral nutrition, and integrated pest management of diseases and pests of avocado, curuba, purple passion fruit, and tree tomatoes oriented towards agronomic management and the development of commercially valuable products" led by LMM, belonging to part of the "National Network for Fruit Bioprospecting - RIFRUTBIO" (contract no. 0459-2013); and project Hermes code 37360 Universidad Nacional de Colombia. Evans Allen fund at Tennessee State University from USDA provided the salary support for MWB (contract no. TENX-07) who was the supervisor of the exchange program Universidad Nacional/TSU under a memorandum of understanding (2014-2019) for student training.

Acknowledgments: We wish to thank the farmers on whose land we planted the experiments in Pasca and Susacón (Carolina Rueda and Rafael Hernández). In addition, we are grateful for advice from the teams of Natalia Rodríguez, Paola Hurtado, Christhian Bayona, Néstor Torres and Orlando Tierranegra in the Plant Physiology lab (Biology Department, UNAL) and Xingbo Wu and Daniel Ambachew of the C4 Genomics lab (Agricultural and Environmental Sciences, TSU). Help from Gustavo Morales (Jardín Botánico José Celestino Mutis- Bogotá) and Fredy Ramos (Ciencias- Química-UNAL) is also appreciated.

Conflicts of Interest: The authors declare no conflict of interest.

\section{References}

1. Angulo, R. Gulupa (Passiflora edulis var edulis Sims); Blackma; Bayer Crop Science: Thane, India, 2009; 36p.

2. Junker, R.; Chung, A.; Blüthgen, N. Interaction between flowers, ants and pollinators: Additional evidence for floral repellence against ants. Ecol. Res. 2007, 22, 665-670. [CrossRef]

3. Ortiz, E.; Cruz, M.; Melgarejo, L.M.; Marquinez, X.; Hoyos-Carvajal, L. Histopathological features of infections caused by Fusarium oxysporum and F. solani in purple passion fruit plants (Passiflora edulis Sims). Summa Phytopathol. 2014, 40, 134-140. [CrossRef]

4. Fischer, G.; Casierra, P.F.; Piedrahita, W. Ecofisiología de las especies pasifloráceas cultivadas en Colombia. Libro de resúmenes Cultivo, Poscosecha y comercialización de las Pasifloráceas en Colombia: Maracuyá, Granadilla, Gulupa y Curuba; Sociedad Colombiana de Ciencias Hortícolas: Bogotá, Colombia, 2009; 350p.

5. Jiménez, Y.; Carranza, C.; Rodríguez, M. Gulupa (Passiflora edulis Sims). In Manual para el cultivo de frutales en el trópico; Fischer, G., Ed.; Produmedios: Bogotá, Colombia, 2012.

6. Lambers, H.; Chapin, F.S.; Pons, T.L. Plant Physiological Ecology; Springer: New York, NY, USA, 1998; 540p.

7. Perez, L.V.; Melgarejo, L.M. Caracterización ecofisiológica de la gulupa (Passiflora edulis Sims) bajo tres condiciones ambientales en el departamento de Cundinamarca. Chapter 1. In Ecofisiología del cultivo de la gulupa (Passiflora edulis Sims); Melgarejo, L.M., Ed.; Editorial Produmedios \& Universidad Nacional de Colombia: Bogotá, Colombia, 2012; 144p.

8. Pérez, L.V.; Melgarejo, L.M. Photosynthetic performance and leaf water potential of gulupa (passiflora edulis sims, Passifloraceae) in the reproductive phase in three locations in the Colombian Andes. Acta Biol. Colomb. 2015, 20, 183-194. [CrossRef]

9. Maxwell, K.; Johnson, G. Chlorophyll fluorescence. A practical guide. J. Exp. Bot. 2000, 51, 659-668. [CrossRef]

10. Sadras, V.; Calderini, D. Applications for breeding and agronomy. Crop Physiol. 2016, 583.

11. Allard, R.W.; Bradshaw, A.D. Implications of Genotype-Environmental Interactions in Applied Plant Breeding. Crop Sci. 1964, 4, 503. [CrossRef]

12. Lüdders, P. Granadilla (Passiflora edulis Sims.) a multiple useful tropical fruit. Erwerbs-Obstbau 2003, 45, 186-191.

13. Galindo, J.; Pacheco, J.; Gómez, S. Gulupa (Passiflora edulis Sims.) Producción y Manejo Poscosecha; Corredor Tecnológico Agroindustrial, CCB, SENA, Universidad Nacional de Colombia, Corpoica, MEGA. Editorial Produmedios: Bogotá, Colombia, 2010.

14. Ocampo, J.; Marin, C.; Posada, P.; Lopez, N.; Solano, R. Establecimiento y zonas productoras del cultivo de la gulupa. In Tecnología para el cultivo de la gulupa (Passiflora edulis f. edulis Sims) en Colombia; 1era edición; Ocampo, J.Y., Wyckhuys, K., Eds.; Centro de Bio-sistemas de la Universidad Jorge Tadeo Lozano, Centro Internacional de Agricultura Tropical CIAT y Ministerio de Agricultura y Desarrollo Rural, Republica de Colombia: Bogotá, Colombia, 2012; 68p.

15. Angel, C.; Nates, G.; Ospina, R.; Melo, C.; Amaya, M. Biología floral y reproductiva de la gulupa Passiflora edulis Sims f. edulis. Caldasia 2011, 33, 433-451. 
16. Cruz, M.; Hoyos, L.; Melgarejo, L.M. Respuesta fisiológica de la gulupa (Passiflora edulis Sims) frente al ataque por Fusarium spp. In Ecofisiología del cultivo de la gulupa (Passiflora edulis Sims); Melgarejo, L.M., Ed.; Produmedios \& Universidad Nacional de Colombia: Bogotá, Colombia, 2012; 144p, Chapter 5.

17. Rendon, J.S.; Ocampo, J.; Urrea, R. Estudio sobre polinización y biología floral en Passiflora edulis f. edulis Sims, como base para el premejoramiento genético. Acta Agron. 2013, 62, 232-241.

18. Gama, V.N.; Cunha, J.T.; De Melo Lima, I.; Bacarin, M.A.; Silva, D.M. Photosynthetic characteristics and quality of five passion fruit varieties under field conditions. Acta Physiol. Plant. 2013, 35, 941-948. [CrossRef]

19. Ocampo, J.A.; Coppensd'eeckenbrugge, G.; Restrepo, M.; Salazar, M.; Jarvis, A. Diversity of Colombian Passifloraceae: Biogeography andean updated list for conservation. Biota Colomb. 2007, 8, 1-45.

20. Solarte, M.E.; Pérez, L.V.; Melgarejo, L.M. Ecofisiología Vegetal. In Experimentos en Fisiología Vegetal; Melgarejo, Ed.; Universidad Nacional de Colombia: Bogota, Colombia, 2010.

21. Allen, R.G.; Pereira, L.S.; Raes, D.; Smith, M. Crop Evapotranspiration-Guidelines for Computing Crop Water Requireents-FAO Irrigation and Drainage Paper 56; Food and Agricultural Organization of the United Nations: Rome, Italy, 2006.

22. Poni, S.; Bernizzonia, F.; Civardi, S.; Gatti, M.; Porro, D.; Camin, F. Performance and water use efficiency (simple leaf vs. whole capopu) of well-watered and half stressed Split root Lambrusco grapevines grown in Po Valley (Italy). Agric. Ecosyst. Environ. 2009, 129, 97-106. [CrossRef]

23. Medrano, H.; Bota, J.; Cifre, J.; Flexas, J.; Ribas, M.; Gulías, J. Eficiencia en el uso del agua por las plantas. Investig. Geogr. 2007, 43, 63-84. [CrossRef]

24. Givnish, T.J.; Montgomery, R.A.; Goldstein, G. Adaptive radiation of photosynthetic physiology in the Hawaiian lobeliads: Light re-gimes, static light responses, and whole-plant compensation points. Am. J. Bot. 2004, 91, 228-246. [CrossRef] [PubMed]

25. Aleric, K.M.; Kirkman, L.K. Growth and photosynthetic response of the federally endangered shrub, Linder amelissifolia (Lauraceae), to varied light environments. Am. J. Bot. 2005, 92, 682-689. [CrossRef]

26. Lichtentthaler, H.K. Chlorophylls and carotenoids: Pigments of photosynthetic biomembranes. Methods Enzymol. 1987, 148, 350-382.

27. Brooks, M.D.; Niyogi, K.K. Use of a pulse-amplitude modulated chlorophyll fluorometer to study the efficiency of photosynthesis in arabidopsis plants. In Chloroplasts Research in Arabidopsis: Methods and Protocols; Volume II, Methods in Molecular Biology; Paul Jarvis, R., Ed.; Humana Press: Totowa, NJ, USA, 2011; Volume 775, pp. 299-310.

28. Lin, D.; Foster, D.; Ungar, L. VIF Regression: A Fast Regression Algorithm for Large Data. Revista de la Asociación Americana de Estadística 2011, 106, 232-247. [CrossRef]

29. Guisande, C.; Heine, J.; García-Roselló, E.; González-Dacosta, J.; García Perez-Schofield, B.J.; González-Vilas, L.; Vaamonde, A.; Lobo, J.M. FactorsR: An RWizard Application for Identifying the MostLikely Causal Factors in Controlling Species Richness. Diversity 2015, 7, 385-396. [CrossRef]

30. Taiz, L.; Zeiger, E. Plant Physiology, 3rd ed.; Collección Ciencies experimentals Num 10; Universitat Jaume: Plana, Spain, 2006; 1339p.

31. Mediavilla, S.; Escudero, A. Stomatal responses to drought of mature trees and seedlings of two co-occurring Mediterranean oaks. For. Ecol. Manag. 2004, 187, 281-294. [CrossRef]

32. Fernández, G.E.; Melgarejo, L.M.; Rodríguez, N. Algunos aspectos de la fotosíntesis y potenciales hídricos de la granadilla (Passiflora ligularis Juss.) en estado reproductivo en el Huila, Colombia. Revista Colombiana de Ciencias Hortícolas 2014, 8, 206-216. [CrossRef]

33. Silva, K. Desempenho de híbridos BRS de maracujazeiros em diferentes altitudes: Caracterização agronômica, ecofisiologia e alelopatia. Ph.D. Thesis, Universidade Federal Do Espírito Santo, Vitória, Brazil, 2018.

34. Romero, J.; Torrente, A.; Obregón, N.; Torres, A. Acople de un modelo de conductancia estomática, fotosíntesis y transpiración para el cultivo de maracuyá (Passiflora edulis Sims). Acta Agron. 2013, 62, 42-51.

35. Gil, J.A.; Rodríguez, R.; Jasso, D.; Zermeño, A. Stomatal Resistance, Transpiration and Water Potential in Aloe vera M. under Different Environmental Conditions. Terra Latinoam. 2006, 24, 355-365.

36. Tominaga, J.; Shimada, H.; Kawamitsu, Y. Direct measurement of intercellular $\mathrm{CO}_{2}$ concentration in a gas-exchange system resolves overestimation using the standard method. J. Exp. Bot. 2018, 69, 1981-1991. [CrossRef] [PubMed]

37. Jones, H. Plants and microclimate. A quantitative approach to environmental. In Plant Physiology, 2nd ed.; Cambridge University Press: New York, NY, USA, 1992. 
38. Souza, P.; Silva, K.; Soares, T.; Nunes, O.; Coelho, M.; Girardi, E. Biometric, physiological and anatomical responses of Passiflora spp. to controlled water deficit. Sci. Hortic. 2018, 229, 77-90. [CrossRef]

39. Sellin, A. Does pre-dawn water potencial reflect conditions of equilibrium in plants and soil water status? Acta Ecol. 1999, 20, 51-59. [CrossRef]

40. Gaudio, M.; Da Luz, C.; Dos Santos, M.; Pimentel, M.; Moura, D.; Falqueto, A. Drought tolerance of passion fruit plants assessed by the OJIP chlorophyll a fluorescence transient. Sci. Hortic. 2012, 142, 49-56.

(C) 2019 by the authors. Licensee MDPI, Basel, Switzerland. This article is an open access article distributed under the terms and conditions of the Creative Commons Attribution (CC BY) license (http://creativecommons.org/licenses/by/4.0/). 